\title{
Microsatellite genotyping from faeces of Lontra longicaudis from southern Brazil
}

\author{
Laura I. Weber ${ }^{1}$, Cintia G. Hildebrand ${ }^{2}$, Anderson Ferreira² ${ }^{2}$ Gustavo Pedarassi ${ }^{3}$, \\ José A. Levy ${ }^{4} \&$ Elton P. Colares ${ }^{3}$
}

1. Departamento de Genética, NUPEM/UFRJ, Caixa Postal 119331, 27901-970 Macaé, RJ, Brazil. (laura.weber@ufrj.br)

2. Laboratório de Genética Molecular, CTTMar, UNIVALI, Rua Uruguai 458, Bloco 20, Sala 212, 88302-202 Itajaí, SC, Brazil.

3. Departamento de Ciências Fisiológicas, FURG, Campus Carreiros, Caixa Postal 474, 96201-900 Rio Grande, RS, Brazil. (epcolares@bol.com.br)

4. Departamento de Química, FURG, Campus Cidade, Caixa Postal 474, 96201-900 Rio Grande, RS, Brazil. (levy@mikrus.com.br)

\begin{abstract}
A genetic study of the neotropical river otter Lontra longicaudis (Olfers, 1818), which has an unknown conservation status, was carried out at the Taim Ecological Station and the margins of the Vargas stream, Rio Grande do Sul, southern Brazil. Faecal samples were collected, and DNA was extracted using a silica-guanidine method. Five microsatellite loci were amplified using PCR with heterologous primers previously described for Lutra lutra (Linnaeus, 1758). Sixteen faecal samples out of 29 from Taim and 11 out of 14 from Vargas stream margins contained enough DNA for genetic analysis. A total of 49 different alleles were found at both localities, from which 18 were exclusively found in individuals from Taim and 17 were exclusives from Vargas individuals. The most common allele was the same at both locations for three loci (Lut715, Lut733, and Lut818). A high level of genetic diversity was found at both sites $\left(\mathrm{Ne}_{\text {Taim }}=4.1, \mathrm{Ho}_{\text {Taim }}=0.299, \mathrm{He}_{\text {Taim }}=0.681 ; \mathrm{Ne}_{\text {Vargas }}=4.9, \mathrm{Ho}_{\text {Vargas }}=0.355, \mathrm{He}_{\text {Vargas }}=0.724\right)$, being higher at the Vargas stream site. A high and significant level of heterozygote deficiency was observed at most loci according to the $\chi^{2}$ test. The homogeneity $\chi^{2}$ test $(P \leq 0.001)$ showed that there were significant differences in the allele frequencies between the two locations. Genotyping for more than one locus was possible in $81.5 \%$ of samples, from which only $37 \%$ were possible to genotype for more than three loci. A low degree of relatedness was found among individuals from Taim $(R=0.055 \pm 0.310)$, but an even lower value of relatedness was found at the Vargas site $(R=$ $-0.285 \pm 0.440)$. The significant degree of differentiation $\left(\mathrm{I}=0.890 ; F_{S T}=0.059\right)$ found between Taim and Vargas individuals suggests that there is more than one population of otters in the southern extreme of Brazil, which probably are associated with the water body systems found in this region, the Mirim and the Caiuvá/Flores/Mangueira Lagoons. The high genetic diversity and low relatedness found at the Vargas stream, lead us to believe that the Vargas stream may be acting as a corridor between these water bodies for otter dispersion.
\end{abstract}

KEYWORDS. Neotropical river otter, genetic markers, Taim, non-invasive sampling, genetic diversity.

RESUMO. Genotipagem através de microsatélites extraídos de amostras fecais em Lontra longicaudis do sul do Brasil. A lontra neotropical de rio Lontra longicaudis (Olfers, 1818), cujo estado de conservação é ainda desconhecido, foi estudada geneticamente na Estação Ecológica do Taim e nas margens do arroio Vargas, RS, sul do Brasil. Amostras de fezes foram coletadas e o DNA foi extraído por um método de sílica-guanidina. Cinco locos de microsatélites foram amplificados por PCR utilizando primers heterólogos previamente descritos para Lutra lutra (Linnaeus, 1758). Dezesseis amostras de fezes de um total de 29 coletadas no Taim e onze das 14 obtidas no arroio Vargas contiveram DNA suficiente para prosseguir com a analise genética. Um total de 49 alelos foram obtidos, dos quais 18 foram exclusivos de indivíduos do Taim e 17 exclusivos dos indivíduos do arroio Vargas. Em três locos (Lut715, Lut733 e Lut818) os indivíduos das duas localidades compartilharam o alelo mais comum. Foi encontrada uma alta diversidade genética $\left(\mathrm{Ne}_{\text {Taim }}=4,1 ; \mathrm{Ho}_{\text {Taim }}=0,299\right.$; $\left.\mathrm{He}_{\text {Taim }}=0,681 ; \mathrm{Ne}_{\text {Vargas }}=4,9 ; \mathrm{Ho}_{\text {Vargas }}=0,355 ; \mathrm{He}_{\text {Vargas }}=0,724\right)$, sendo esta maior no arroio Vargas. Uma alta e significativa deficiência de heterozigotos foi observada em quase todos os locos de acordo com o teste do $\chi^{2}$. O teste do $\chi^{2}$ de homogeneidade genética $(P \leq 0,001)$ mostrou diferenças significativas entre as frequiências alélicas das duas localidades. A genotipagem para mais de um loco foi possível em $81,5 \%$ das amostras, sendo que somente em $37 \%$ destes foi possível a genotipagem para mais de três locos. Foi encontrado um baixo grau de parentesco entre os indivíduos do Taim $(R=0,055 \pm 0,310)$, sendo este ainda menor nos indivíduos do arroio Vargas $(R=-0,285 \pm 0,440)$. O grau significativo de diferenciação genética $\left(\mathrm{I}=0,890 ; F_{S T}=0,059\right)$ entre os indivíduos do Taim e do arroio Vargas sugere a existência de mais de uma população de lontras no extremo sul do Brasil, que provavelmente estejam associadas aos diferentes corpos de água existentes nesta região: a Lagoa Mirim e o sistema de lagoas Cauivá/Flores/Mangueira. A alta diversidade genética e o baixo grau de parentesco dos indivíduos do arroio Vargas nos leva a considerar a possibilidade que o arroio Vargas possa estar atuando como um corredor entre estes corpos de água para a dispesão das lontras.

PALAVRAS-CHAVE. Lontra neotropical de rio, marcadores genéticos, Taim, amostragem não-invasiva, diversidade genética.

The neotropical river otter Lontra longicaudis (Olfers, 1818) (Carnivora, Mustelidae) can be found from north-western Mexico to northern Argentina (LARIVIÈRE, 1999) in a great variety of habitats, including small forests, riparian vegetation, streams, rivers, lakes, swamps, and marine coasts occupying savannas associated with freshwater lagoons (MASON, 1990; Rosas et al., 1991; BLACHER, 1992). The river otters have a long lifespan, $L$. canadensis (Schreber, 1777) reaches 13 years of age in the wild (DосктоR et al., 1987), and reproductive activities may begin very early in life (Hamilton \& EAdiE, 1964;
DockTOR et al., 1987). Nowadays there is a reduction in the population size of the otter L. longicaudis, that has been attributed to habitat destruction by human activities, such as deforestation and hydroelectric dam construction (Melquist, 1984; MacDonald \& Mason, 1990). Water pollution and heavy navigation have been shown to diminish the use of habitats by aquatic mammals (Pteronura brasiliensis (Gmelin, 1788), Lontra longicaudis, Trichechus inunguis (Natterer, 1883)) (RosAS et al., 1991). Pollution reduces the marginal vegetation of rivers and lagoons, which has been found to be important 
for the permanent residence of other related mustelids (BAs et al., 1984). Furthermore, direct hunting activities for the fur trade diminished the otter population considerably since the middle of the last century (RosAS et al., 1991; LARIVIÉRE, 1999). Therefore, the species has been considered vulnerable (CHEHÉBAR, 1990), and since 1975, it has been in Appendix I of the list of endangered species prepared by the Convention on International Trade in Endangered Species of Wild Fauna and Flora (CITES) (CITES, 1977; UNEP-WCMC, 2003). In 1983, the Brazilian government included this species on the list of Brazilian threatened species through IBAMA (MMA, 1999). Nonetheless, it was removed from the national IBAMA list of endangered species in May 2003 (MMA, 2003), and its conservation status remains "Data deficient" (IUCN, 2007) due to the absence of population genetic studies, which would allow analysis of the degree of conservation and genetic risk of the species.

Lontra longicaudis runs away from humans, and therefore it cannot be directly observed. Consequently, individuals are mainly detected by indirect evidence, such as the characteristic burrows where they live, footprints, and spraints (BLACHER, 1992). Faeces have been used as a non-invasive means of collecting samples for DNA extraction in a variety of mammals (TABERLET et al., 1997; WASSER et al., 1997; FlAGSTAD et al., 1999; KoHN et al., 1999; MorIn et al., 2001). For population genetic studies of endangered species, it is desirable to use non-invasive samples in order to decrease the risks involved in the capture. However, working with faeces is difficult, because intestinal cells are not homogeneously distributed in faecal material (WASSER et al., 1997) and faecal DNA starts degradation soon after deposition (Morin \& WoOdRUFF, 1996), therefore faecal DNA is found in low quantity and poor quality (Nsubuga et al., 2004). Since microsatellites are short sequences, they are more appropriate for the detection of genetic polymorphisms in highly degraded DNA, because the amplification success is inversely related to fragment length (BROQUET et al., 2007). A number of primers suitable for the amplification of microsatellites in the Eurasian otter Lutra lutra (Linnaeus, 1758) were described by Dallas \& Piertney (1998). These primers were also useful for analyzing genetic variability in the river otter Lontra canadensis (BLUNDELL et al., 2002b) and sea otter Enhydra lutris (Linnaeus, 1758) (LARSON et al., 2002a,b). As L. longicaudis has been considered a subspecies of L. canadensis by some authors (Hershrovitz, 1972; DAvis, 1978), and more recently, studies have shown that these two species are very closely related (Koepfli \& Wayne, 1998; 2003), we expected that these primers would also be useful for studying the neotropical otter L. longicaudis. Therefore, our first aim was to test these primers in the amplification of L. longicaudis microsatellite loci, and to determine if it was possible to genotype individuals at multiple loci from faecal samples. Our second goal was to study the genetic composition of L. longicaudis at two geographical sites in the south of Brazil, in order to evaluate population division, genetic diversity, and dispersion of individuals between the protected area of the Taim Ecological Station and the unprotected surroundings of the Vargas stream.

\section{MATERIAL AND METHODS}

Sampling areas and collections. Two areas were chosen for collecting samples: the Estação Ecológica do Taim (Taim Ecological Station), 3240'S, 52 $2^{\circ} 50^{\prime} \mathrm{W}$, hereafter only Taim and the margins of the Vargas stream (32 $30^{\circ} \mathrm{S}$, $\left.52^{\circ} 30^{\prime} \mathrm{W}\right)$ at the southern most extreme of Brazil.

The Taim (Fig. 1) was founded in July 1987, with the aim of protecting fauna common to local marshes and swamp areas. It comprises 100,000 ha between the Atlantic Ocean and the Mirim Lagoon at the southern most extreme of Brazil, and is $70 \mathrm{~km}$ from the nearest city, Rio Grande. The subtropical climate of this region has an annual mean temperature of $18^{\circ} \mathrm{C}$, and an annual pluvial mean of 1,100 mm (SEMA, 1977). The geomorphology is smooth, and rich in dunes and plains interrupted by drainage and swamps from the Patos, Mirim, and Mangueira lagoons. The vegetation is rich in macrophytes, peats, and sandy restinga forest, and there are also some dry areas and patchy forests. The Taim is situated on both sides of the main road that leads to the Uruguay border. Mortality of the animals due to motor vehicles was decreased by the construction of strong, high fences on both sides of the road. Underground tubes allow the animals to safely pass from one side of the road to the other. Twenty-nine faecal samples were collected over a distance of $10 \mathrm{~km}$ from September 2000 to December 2001 at the Taim. Frozen lung tissue from an individual that was found dead on the BR-471 road that accesses the Taim in 1997 (Fig. 1) was used to test the primers.

The Vargas stream (Fig. 1) is situated $5 \mathrm{~km}$ north of the Taim and extends for approximately $18 \mathrm{~km}$, and crosses the land from east to west. It is a private property, and is not subject to government protection. The margins of the Vargas stream are similar to the Taim, but contain longer extensions of swamps, sandy areas, and scattered forests than the Taim. The climate conditions are also similar to the Taim. It was difficult to obtain samples due to rain washout, and therefore, we were unable to collect a more representative sample size in the short period of

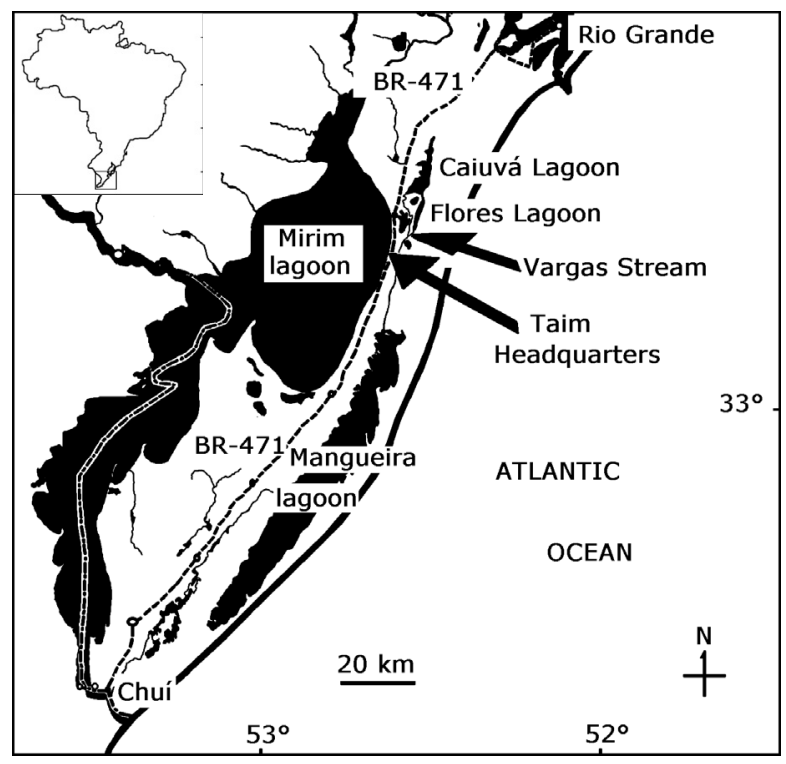

Fig. 1. South Brazil. Arrows indicate sampling sites. 
time used for the study. Lontra longicaudis faeces were identified by their characteristic smell and composition. Fourteen samples were collected from a stretch of $2 \mathrm{~km}$ from September 2000 to December 2001 at the margins of the Vargas stream. Wet samples were stored in $50 \mathrm{ml}$ sterilized conical tubes containing sterilized filter paper and silica particles up to a volume of $40 \mathrm{ml}$. Dry samples were directly stored in sterilized Petri dishes containing sterilized filter paper. Both types of sample were stored at $-18^{\circ} \mathrm{C}$ until DNA extraction.

DNA extraction. DNA was extracted from lung tissue once and from each faecal sample in at least triplicate by following a silica-guanidine protocol (HoElzEL, 1998). Two hundred milligrams of each sample was incubated in $1 \mathrm{~mL}$ of lysis buffer (50 mM Tris- $\mathrm{HCl}$; 25 mM EDTA, pH 8.0; 1.25\% Triton-X-100; 5 M GuSCN) overnight. The next morning, the tubes were centrifuged at $16,000 \mathrm{x} g$ at $16^{\circ} \mathrm{C}$ for $10 \mathrm{~min}$. Afterwards, $700 \mathrm{~mL}$ of the supernatant was transferred to fresh tubes, to which 700 mL of DNA binding solution (50 mM Tris- $\mathrm{HCl} ; 25 \mathrm{mM}$ EDTA, pH 8.0; 5 M GuSCN; 1\% silica slurry) was added and solutions were mixed in a rotating wheel for two hours. The tubes were then centrifuged at $16^{\circ} \mathrm{C}$ at maximum speed for $5 \mathrm{~min}$. The supernatants were discarded and the pellets containing silica and DNA were washed three times with $70 \%$ ethanol. The pellets were then dried, and the DNA was resuspended in $80 \mathrm{~mL}$ of TE (10mM Tris$\mathrm{HCl}, \mathrm{pH}$ 7.4; 1 mM EDTA, $\mathrm{pH}$ 8.0).

Microsatellite amplification and separation. The primers described by DALlas \& PIERTNEY (1998) for the amplification of the microsatellite loci Lut457, Lut701, Lut715, Lut733, Lut782, and Lut818 of L. lutra were tested in L. longicaudis. Hot start and touchdown PCR was performed using the following steps: 1 cycle at $94^{\circ} \mathrm{C}$ for $150 \mathrm{~s}, 20$ cycles at $90^{\circ} \mathrm{C}$ and $60^{\circ} \mathrm{C}$ (lowering in $0.5^{\circ} \mathrm{C}$ each cycle) for $15 \mathrm{~s}$ each, 15 cycles at $90^{\circ} \mathrm{C}$ and $50^{\circ} \mathrm{C}$ for $15 \mathrm{~s}$ each, with a final extension step of $1 \mathrm{~min}$ at $72^{\circ} \mathrm{C}$. Each $25 \mu \mathrm{l}$ PCR reaction contained $5 \mu$ DNA template, $2.5 \mu \mathrm{l} 10 \mathrm{x}$ PCR buffer (Invitrogen), $2.5 \mathrm{mM} \mathrm{MgCl}_{2}, 5 \mu \mathrm{g}$ Bovine Serum Albumin (BSA), $200 \mu \mathrm{M}$ of each dNTP, $0.5 \mu \mathrm{M}$ of each primer, and $1 \mathrm{U}$ hot-start Platinum Taq Polymerase (Gibco). In order to increase the quantity of PCR products a second round of PCR was performed using the same conditions with $1 \mu \mathrm{l}$ of the PCR product from the first amplification as a template. The PCR products were separated by size in a $6 \%$ denaturing polyacrylamide gel containing $7 \mathrm{M}$ urea. They were denatured for $5 \mathrm{~min}$ at $95^{\circ} \mathrm{C}$ in $95 \%$ formamide loading buffer before loading them onto the gel. Electrophoresis was done at $45 \mathrm{~W}$ for $2 \mathrm{~h}$ at $50-55^{\circ} \mathrm{C}$. The DNA fragments were visualized by silver staining according to the protocol described by HoElzel (1998).

Data Analysis. Allele frequencies and diversity parameters were obtained using POPGENE v.1.3 software (RAYMOND \& RousSET, 1995). Biosys-I software (SwOFFORD \& Selander, 1981) was used to obtain F-statistics, heterozygote deficiency (D), $\chi^{2}$ goodness of fit to the Hardy-Weinberg equilibrium, $\chi^{2}$ homogeneity test and genetic identity (NEI, 1978) between locations. The probability that samples that were genetically identical belonged to the same individual was calculated in accordance with Huston (1998), using the formulae for the discriminant power of combined loci $\left(\mathrm{P}_{\mathrm{d}}\right): \mathrm{P}_{\mathrm{d}}=1-\prod\left(\mathrm{P}_{\mathrm{M}}\right)$, where $\mathrm{P}_{\mathrm{M}}$ represents the matching probability of a locus, calculated independently as $P_{M}=\Sigma\left(G_{i}^{2}\right)$, and where $G_{i}$ corresponds to all possible genotypes at the locus. The degree of relatedness (R) was calculated for all pairs of individuals that were scored for at least three loci, in accordance with QUELLER \& GOODNIGHT (1989). The mean and standard deviation of the relatedness were calculated for each location, and also for both locations grouped as a single unit. The degree of sociality was calculated in accordance with the classification of BLundeLl et al. (2002a).

\section{RESULTS}

The six microsatellite loci (Lut457, Lut701, Lut715, Lut733, Lut782, and Lut818) were successfully amplified using lung tissue from Lontra longicaudis, thus demonstrating that all the primers that were described for Lutra lutra may be used for population analysis of Lontra longicaudis.

Only 16 faecal samples from the Taim and 11 from the Vargas stream margins contained enough DNA to proceed with genetic analysis. Two rounds of PCR amplification were required from faecal DNA, and even using these conditions, the reaction was only $40 \%$ of the maximum efficiency (Fig. 2). The Lut782 microsatellite was excluded, because it did not give interpretable results for most individuals, therefore, we only analyzed five loci (Tab. I).

A total of 49 different alleles were found at the five loci at both localities, from which 18 were exclusively found in individuals at the Taim and 17 were found exclusively in individuals from Vargas stream. The most common allele was shared by individuals from both locations for the Lut715, Lut733, and Lut818 loci. A larger effective number of alleles, and a higher degree of heterozygosity were observed at the Vargas stream compare to the Taim (Tab. II). The Lut715 microsatellite had the largest number of alleles at the Taim, while the Lut457 microsatellite had the most alleles at the Vargas stream.

A high heterozygote deficiency was found at almost all of the loci analyzed at both sites (Tab. II). In accordance with a $\chi^{2}$ test of goodness of fit to the HardyWeinberg equilibrium (H-W), 4 of 5 loci showed significant deviation from the $\mathrm{H}-\mathrm{W}$ equilibrium at the Taim and only one of 5 at the Vargas site. In accordance with the Fisher's exact test (which pools rare alleles), all loci were in $\mathrm{H}-\mathrm{W}$ equilibrium at Vargas, while at the Taim, only Lut457 deviated significantly from $\mathrm{H}-\mathrm{W}$ equilibrium (Tab. II). Measures of genetic differentiation $(\mathrm{I}=0.890$; $\left.F_{S T}=0.059\right)$ showed that there was a moderate degree of population division between the Taim and the Vargas site. Similar and lower values of $F_{S T}$, which showed significant population division, were also found in other species (see HartL \& CLARK, 1989; GiBBS et al., 1997; EscorZA- Treviño \& Dizon, 2000; Trujillo et al., 2004; WurfF et al., 2005). A homogeneity $\chi^{2}$ test confirmed the population division of $L$. longicaudis $\left(P<0.001 ; \alpha^{\prime}=0.01\right)$ after a Bonferroni correction for multiple testing (RICE, $1988)$, and the Lut457 ( $\left.\chi^{2}=24.27 ; P<0.001\right)$ and Lut715 


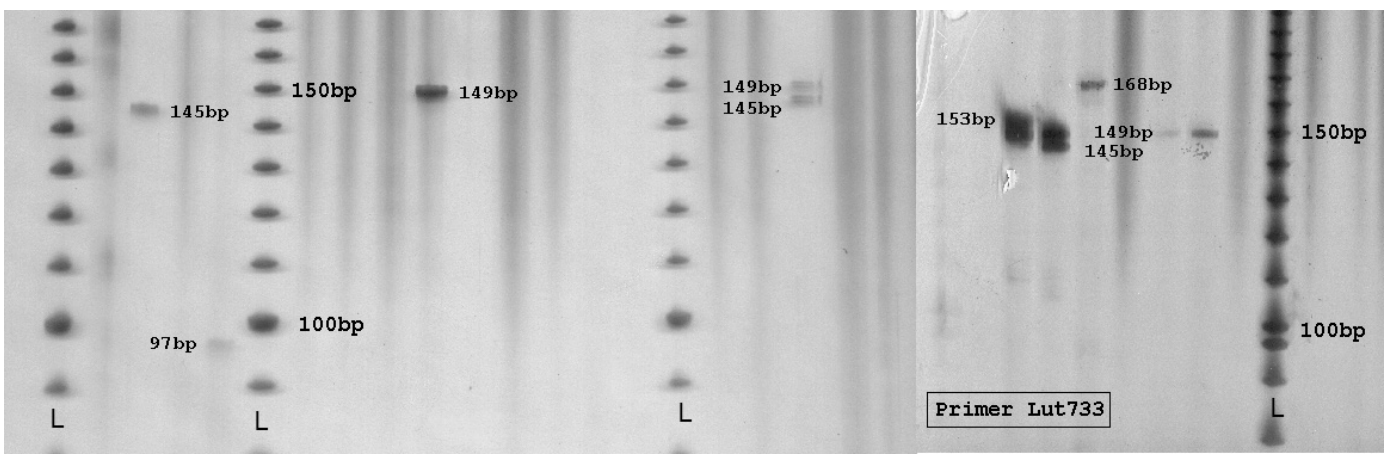

Fig. 2. Microsatellite alleles (97, 145, 149, 153, and 168 bp) of the Lut733 locus in L. longicaudis (Olfers, 1818) after 6\% polyacrylamide vertical gel electrophoresis and silver staining. (L) 10 bp ladder (Invitrogen).

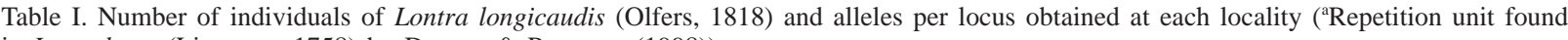
in Lutra lutra (Linnaeus, 1758) by Dallas \& Piertney (1998)).

\begin{tabular}{|c|c|c|c|c|c|c|}
\hline \multirow[t]{2}{*}{ Locus } & \multirow{2}{*}{$\begin{array}{l}\text { Repetition } \\
\text { unit }^{\mathrm{a}}\end{array}$} & \multirow[t]{2}{*}{ Locality } & \multirow{2}{*}{$\begin{array}{l}\text { Number of } \\
\text { individuals }\end{array}$} & \multicolumn{3}{|c|}{ Number of alleles } \\
\hline & & & & Per locus & Exclusive & Total \\
\hline \multirow[t]{2}{*}{ Lut457 } & $(\mathrm{CA}) \mathrm{n}$ & Taim & 12 & 8 & 5 & \\
\hline & & Vargas & 9 & 12 & 9 & 17 \\
\hline \multirow[t]{2}{*}{ Lut701 } & $(\mathrm{GATA})_{\mathrm{n}} \mathrm{GAA}$ & Taim & 13 & 5 & 1 & \\
\hline & $(\text { GATA })_{n}$ GAA $(\text { GATA })_{n}$ & Vargas & 7 & 5 & 1 & 6 \\
\hline \multirow[t]{2}{*}{ Lut715 } & $(\text { GATA })_{\mathrm{n}} \mathrm{GAT}$ & Taim & 8 & 9 & 8 & \\
\hline & $(\text { GATA })_{n}$ GAT $(\text { GATA })_{n}$ & Vargas & 4 & 5 & 4 & 14 \\
\hline \multirow[t]{2}{*}{ Lut733 } & $(\text { GATA })_{n}$ GAT $(\text { GATA })_{n}$ & Taim & 6 & 4 & 1 & \\
\hline & & Vargas & 5 & 6 & 3 & 7 \\
\hline \multirow[t]{2}{*}{ Lut818 } & $(\text { GATA })_{n}$ & Taim & 9 & 5 & 3 & \\
\hline & & Vargas & 3 & 2 & 0 & 5 \\
\hline
\end{tabular}

Table II. Genetic diversity, heterozygote deficiency and goodness of fit to Hardy-Weinberg equilibrium at each locus in Lontra longicaudis (Olfers, 1818) (aeffective number of alleles; 'observed heterozygosity, direct count; 'expected heterozygosity (NeI, 1978); ${ }^{\mathrm{d} N e g a t i v e}$ values of D indicate hererozygote deficiency; ${ }^{\mathrm{e}} \mathrm{Hardy}$-Weinberg equilibrium; *significant at the level of $\alpha$ ' $\alpha / 5=0.01$ after Bonferroni correction for multiple tests (RICE, 1988)).

\begin{tabular}{|c|c|c|c|c|c|c|c|c|c|c|c|c|}
\hline \multirow[t]{3}{*}{ Locus } & \multicolumn{6}{|c|}{ Taim } & \multicolumn{6}{|c|}{ Vargas stream } \\
\hline & \multicolumn{3}{|c|}{ Genetic Diversity } & \multicolumn{3}{|c|}{$\begin{array}{l}\text { Heterozygote deficiency } \\
\text { and Goodness of fit to H-W }\end{array}$} & \multicolumn{3}{|c|}{ Genetic Diversity } & \multicolumn{3}{|c|}{$\begin{array}{l}\text { Heterozygote deficiency } \\
\text { and Goodness of fit to H-W }\end{array}$} \\
\hline & $\mathrm{Ne}^{\mathrm{a}}$ & $\mathrm{Ho}^{\mathrm{b}}$ & $\mathrm{He}^{\mathrm{c}}$ & $\mathrm{D}^{\mathrm{d}}$ & $\begin{array}{c}\chi^{2} \text { Test } \\
\text { Probability }\end{array}$ & $\begin{array}{l}\text { Fisher Exact } \\
\text { Probability }\end{array}$ & $\mathrm{Ne}^{\mathrm{a}}$ & $\mathrm{Ho}^{\mathrm{b}}$ & $\mathrm{He}^{\mathrm{c}}$ & $\mathrm{D}^{\mathrm{d}}$ & $\begin{array}{c}\chi^{2} \text { Test } \\
\text { Probability }\end{array}$ & $\begin{array}{l}\text { Fisher Exact } \\
\text { Probability }\end{array}$ \\
\hline Lut457 & 5.0 & 0.167 & 0.812 & -0.803 & $<0.001 *$ & $0.001 *$ & 10.0 & 0.444 & 0.901 & -0.534 & $<0.001 *$ & 0.293 \\
\hline Lut701 & 4.0 & 0.231 & 0.772 & -0.713 & $<0.001 *$ & 0.011 & 3.6 & 0.429 & 0.724 & -0.451 & 0.038 & 0.440 \\
\hline Lut715 & 6.7 & 0.375 & 0.852 & -0.587 & $<0.001 *$ & 0.022 & 4.0 & 0.500 & 0.750 & -0.417 & 0.145 & 0.554 \\
\hline Lut733 & 2.1 & 0.500 & 0.514 & -0.108 & 0.080 & 0.970 & 5.0 & 0.400 & 0.800 & -0.550 & 0.022 & 0.625 \\
\hline Lut818 & 1.8 & 0.222 & 0.457 & -0.541 & $<0.001 *$ & 0.059 & 1.8 & 0.000 & 0.444 & -1.000 & 0.021 & 0.200 \\
\hline Mean & 4.1 & 0.299 & 0.681 & & & & 4.9 & 0.355 & 0.724 & & & \\
\hline$\pm \mathrm{SD}$ & & \pm 0.061 & \pm 0.082 & & & & & \pm 0.090 & \pm 0.076 & & & \\
\hline
\end{tabular}

$\left(\chi^{2}=21.43 ; P=0.008\right)$ loci explained the differentiation between the Taim and the Vargas stream populations. Private alleles found exclusively at the Taim (18 alleles) and at Vargas (17 alleles) also explained the differentiation between individuals from the different sites.

Genotyping at more than one locus was possible only in $81.5 \%$ of the scored samples, from which $37 \%$ were evaluated for more than three loci. A total of 24 different genotypes were detected. Identical genotypes were only found at the Taim. One individual found at the Taim in January 2001 had a very high probability $(99.38 \%$ from four loci) of being the same individual that was found $1 \mathrm{~km}$ away in April of the same year. In another case, faecal samples found on the same day, but $100 \mathrm{~m}$ apart, had a high probability to belong to the same individual (91.13\% from two loci). It was also suspected that two of the other samples belonged to a single individual (97.57\%), because the two samples had the same genotype at one locus, and had a very rare allele. Five loci may be sufficient to identify individuals, but nine to ten loci would be necessary to avoid inaccurately identifying a match between two related individuals, specially if heterozygosity values are low $(0,2-0,4)$ (WAITs et al., 2001), which was the case in the present study. As we cannot rule out the possibility that close relatives shared the same genotypes at small number of loci, we 
decided to perform statistical analyses assuming that all genotypes found come from different individuals.

A low degree of relatedness among all individuals $(R=0.061 \pm 0.392)$ was found. At the Taim, individuals showed a higher degree of relatedness $(R=$ $0.055 \pm 0.310)$ than individuals from the Vargas stream $(R=$ $-0.285 \pm 0.440)$. We detected that 11 out of 16 sampled points had more than one spraint, and of these points, six contained faeces from different individuals. Therefore, the species shows at least $29.4 \%$ sociality, which is within the range of moderate sociality in accordance with the classification of BLUNDELL et al. (2002a).

\section{DISCUSSION}

We encountered many problems while amplifying DNA from faecal samples. Morin et al. (2001) demonstrated that quantities of DNA smaller than $25 \mathrm{pg}$ are not feasible for PCR amplification, and that pooling samples from the same spraint does not always produce good results. This is because as DNA concentration is increased, the concentrations of PCR inhibitors are also increased (BROQUET et al., 2007). We partly solved this problem by re-amplifying the samples using two rounds of PCR, and by improving some of the conditions from the original protocol described by Dallas \& PierTneY (1998). Re-amplification increased the success of microsatellite amplification to almost $40 \%$. We predicted that the novel multiplex-two step PCR methods that were recently described by PIGGOTT et al. (2004) may be useful in this species. Recently, when working with another population, BANEvicius (2005) was able to increase the success of PCR amplification by adding the samples directly to the lysis buffer, adding a PCR extension step, and increasing the time of each PCR cycle.

We detected a drop-out allele (ADO) effect where there is a stochastic amplification of only one of the alleles of a heterozygote individual (Morin et al., 2001) by observing that homozygotes after one round of PCR were actually heterozygotes after two or three rounds of PCR. Drop-out allele errors were estimated by MoRIN et al. (2001) to be between $5.2 \%$ and $42 \%$, depending on the initial DNA template.

All of the loci analyzed were highly polymorphic, and the most variable loci was Lut457, which had a total of 17 alleles out of the 49 found across all loci. The Lut 457 microsatellite is a dinucleotide (CA) repeat in Lutra lutra (Dallas \& Piertney, 1998), and we predict that $L$. longicaudis also has this repetitive motif, which may also explain the high diversity at this locus found in this species. The microsatellite motif has been shown to affect the success of amplification and the rate of ADO (BROQUET et al., 2007). These authors observed that dinucleotide motifs have a higher success of amplification and lower ADO than tri- or tetranucleotide microsatellites.

A low degree of heterozygosity was observed when compared to the expected value, which explains the departure from Hardy-Weinberg equilibrium at most loci in accordance with the $\chi^{2}$ test. When pooling rare alleles by Fisher's exact probabilities (LEVENE, 1949), only Lut457 at the Taim showed deviation from $\mathrm{H}-\mathrm{W}$ equilibrium. Rare alleles (in low frequency) may be responsible for the significant heterozygote deficiencies found by Chi-square tests, due to a false rejection caused by the many alleles in low frequencies, where the exact test is recommended (Levene, 1949; Guo \& Thompson, 1992). The observed heterozygote deficiency may partly result from the ADO effect, which is a common problem when working with faeces (NAvidi et al., 1992; Morin et al., 2001). Heterozygosity also affects ADO, and an increase in heterozygosity of $10 \%$ may elevate ADO by $12.2 \%$ (BROQUET et al., 2007). However, we were unable to perform 7 replicates of each PCR amplification for every sample in order to diminish ADO error, as recommended by BROQUET et al. (2007). Heterozygote deficiency may also be the result of inbreeding due to a small population size or due to the Wahlund effect. The high allelic diversity found in the studied area is not in accordance with a small population size, and long distance dispersal of individuals between reproductive sites along feeding and transit areas may lead to the Wahlund effect. However, the use of small sample sizes when studying highly polymorphic loci may also prevent the detection of the true levels of heterozygosity (Delany et al., 2000).

A higher level of genetic diversity was found at the Vargas stream than inside the Taim, although the sample size and collection area were larger at the Taim. This result was unexpected. However, we realized that the Vargas stream is protected from human interference because it is located far from the main road, and entrance to the site is only allowed by the owners permission, therefore, Vargas represents an undisturbed population. The Taim is subject to a greater degree of human interference by car movements along the road. In addition, the reserve station was only established 18 years ago, which may not have been enough time for the damaged population to recover.

The observed differences in allele frequencies between the Taim and the Vargas stream led us to reject the null hypothesis of a single population, and we demonstrated that there are at least two different populations of the neotropical otter in the southern extreme of Brazil. We expect that the population of $L$. longicaudis at the Taim is represented by individuals that are mainly distributed over the Mirim Lagoon system, and individuals collected at the Vargas stream may belong to the Caiuvá/Flores/Mangueira Lagoon systems. Further studies over a longer period of time and sampling a larger number of individuals will be necessary to test the hypothesis that there are different populations associated with the Mirim and Caiuvá/Flores/Mangueira lagoons.

The home range of $L$. canadensis was estimated to be $\sim 12-40 \mathrm{~km}$ by BOWYER et al. (2003) and BLUNDELL et al. (2004), with a natal dispersal of up to $90 \mathrm{~km}$ in females, whereas males may disperse up to $65 \mathrm{~km}$ for the breeding season (Blundell et al., 2004). Since L. longicaudis is very closely related to $L$. canadensis (KoEPFLI \& WAYNE, 1998; 2003), we expect that there are similar patterns of long distance dispersal in L. longicaudis. It is probable that the short duration of sampling and the small sample size prevent us from being able to detect the dispersion of individuals between the reserve and Vargas margins.

The high variance of the mean relatedness found in the present study was also observed by BLUNDELL et al. (2004) in the river otter L. canadensis. The mean value 
found at the Taim $(R=0.055 \pm 0.310)$ is similar to the values found by these authors for the river otter at two localities in Alaska, USA. No values as low as the observed in Vargas $(R=-0.285 \pm 0.440)$ were found in the river otter. Our estimations of relatedness were obtained from only three loci in each pair-wise calculation; therefore these values may not be accurate. BLundell et al. (2004) reported that three loci are not enough to accurately estimate the degree of relatedness, however the low values of relatedness observed in the Vargas stream may be explained by other factors. The Vargas stream may act as a corridor between the different lagoon systems, specifically between the Flores/Caiurá and Mangueira Lagoons, and could also act as a transit and feeding region to the Mirim Lagoon, where the Taim reproductive sites are found.

In contrast, the Taim provides a good location for reproduction sites. One site is located very close to the Taim headquarters, and females and litters have frequently been observed there. It is assumed that otters remain at these sites for long periods until litters reach independence. The lower variability observed at Taim, together with the higher degree of relatedness among Taim individuals when compared to Vargas, is also consistent with this idea.

A low degree of relatedness supports low territorialism and more sociable individuals. L. canadensis exhibits no male territorialism, a low degree of relatedness between individuals, and mainly consists of social individuals (BLunDELL et al., 2004). Although our results have to be considered with caution, the data are suggestive of low territorialism and moderate sociality in L. longicaudis, in accordance with the classification of Blundell et al. (2002a). A number of factors have been cited to explain the low relatedness observed in $L$. canadensis, such as high intra-local diversity, high dispersal, high sociality, non-preferred kin association, and lack of kin avoidance (BLUNDELl et al., 2002a; 2004).

Further genetic data is required to test the hypothesis that there are different populations in the water bodies at the southern extreme of Brazil, and whether the Vargas stream acts as a corridor between these water bodies, and whether the Neotropical otter L. longicaudis exhibits similar behaviour to $L$. canadenses.

Acknowledgments. To Fundação O Boticário de Proteção à Natureza (FBPN-00434220001 Project) and to Fundação de Amparo à Pesquisa of Rio Grande do Sul (FAPERGSRD-00/1325 Project) for financial support. We also thank ProBic/ UNIVALI program for the grant given to $\mathrm{CGH}$ and also to $\mathrm{CNPq}$ and the American Genetics Association for a grant given to LIW for attending the course Recent Advances in Conservation Genetics, Smithsonian Institution, Virginia, USA. To the Director of the Estação Ecológica do Taim, Amauri B. Sena Motta, for sampling facilities.

\section{REFERENCES}

Banevicius, N. M. S. 2005. Aspectos ecológicos da lontra (Lontra longicaudis) no ecossistema da Lagoa do Perí, SC, Brasil. MSC. Thesis, Universidade do Vale do Itajaí, Brazil, p.81.

Bas, N.; Jenkins, D. \& Rother, Y. P. 1984. Ecology of otters in northern Scotland. The distribution of otter (Lutra lutra) feces in relation to bankside vegetation on the river dee in summer 1981. Journal of Applied Ecology 21:507-513.
Blacher, C. 1992. A Lontra. Aspectos de sua Biologia, Ecologia e Conservação. Florianópolis, UFSC e IBAMA p.27.

Blundell, G. M.; Ben-David, M. \& Bowyer, R. T. 2002a. Sociality in river otters: cooperative foraging or reproductive strategies? Behavioral Ecology 13:134-141.

Blundell, G. M.; Ben-David, M.; Groves, P.; Bowyer, R. T. \& Gefren, E. 2002b. Characteristics of sex-biased dispersal and gene flow in coastal river otters: implications for natural recolonization of extirpated populations. Molecular Ecology 11:289-303

2004. Kinship and sociality in coastal river otters: are they related? Behavioral Ecology 15:705-714

Bowyer, R. T.; Blundell, G. M.; Ben-David, M.; Jewett, S. C.; Dean, T. A. \& Duffy, L. K. 2003. Effects of the Exon Valdez oil spill on river otters: injury and recovery of a sentinel species. Wildlife Monographs 153:1-53.

Broquet, T.; Ménard, N.; Petit, E. 2007. Noninvasive population genetics: a review of sample source, diet, fragment length and microsatellite motif effects on amplification success and genotyping error rates. Conservation Genetics 8:249-260.

Chehébar, C. 1990. Action Plan for Latin American Otters. In: Foster-Turley, P.; MacDonald, S. \& Mason, C. eds. Otters. An Action Plan for their Conservation. Cambridge, IUCN Publication Services Unit. p.64-73.

CITES (Convention on International Trade in Endarged Species of Wild Fauna and Flora). 1977. Appendices I, II, and III to Convention on International Trade in Endangered species of wild Fauna and Flora. Arlington, U.S. Fish \& Wildlife Service. p.24.

Dallas, J. F. \& Piertney, S. B. 1998. Microsatellite primers for the Eurasian Otter. Molecular Ecology 7:1247-1263.

Davis, J. A. 1978. A classification of the Otters. In: Duplaix, N. ed. Otters: Proceedings of the First Working Meeting of the Otter Specialist Group. Morges, Switzerland, IUCN p. 14-33.

Delany, M. F.; Giesel, J. T. \& Brazeau, D. A. 2000. Genetic variability among populations of thre Florida Grasshopper sparrow. Journal of Wildlife Management 64:631-636.

Docktor, R. A.; Bowyer, R. T. \& Clark, A. G. 1987. Number of corpora lutea as related to age and distribution of river otters in Maine. Journal of Mammalogy 68:182-185.

Escorza-Treviño, S. \& Dizon, A.E. 2000. Phylogeography, intraspecific structure and sex-biased dispersal of Dall's porpoise, Phocoenoides dalli, revealed by mitochondrial and microsatellite DNA analyses. Molecular Ecology 9:10491060 .

Flagstad, Ø.; Røed, K.; Stacy, J. E. \& Jakobsen, K. S. 1999 Reliable noninvasive genotyping based on excremental PCR of nuclear DNA purified with magnetic bead protocol. Molecular Ecology 8:879-883.

Gibbs, H. L.; Prior, K. A.; Weatherhead, P. J. \& Johnson, G. 1997. Genetic structure of populations of the threatened eastern massasauga rattlesnake, Sistrurus c. catenatus: evidence from microsatellite markers. Molecular Ecology 6:1123-1132.

Guo, S. W. \& Thомsom, E. A. 1992. Performing the exact test for hardy-Weinberg proportions for multiple alleles. Biometrics 48:361-372.

Hamilton JR., W. J. \& Eadie, W. R. 1964. Reproduction in the otter, Lutra canadensis. Journal of Mammalogy 45:242252

Hartl, D. L. \& Clark, A. G. 1989. Principles of Population Genetics. 2nd. ed. Sunderland, Sinauer Associates. p.682.

HeRshKovitz, P. 1972. Recent mammals of the neotropical region: a zoogeographical and ecological review. In: KeAST, A.; ERK F. O. \& Glass, B. eds. Evolution, Mammals and Southern Continents. New York, New York State University. p.100-101.

Hoelzel, A. R. 1998. Molecular genetic Analysis of Populations. A Practical Approach. Oxford, Oxford University. p.445

Huston, K. 1998. A Statistical analysis of STR data. Profiles in DNA 1:14-15.

IUCN (International Union for the Conservation of Nature and Natural Resources). 2007. IUCN RedList of Threatened species. Available at: <www.iucnredlist.org> Accessed on: 17.02 .2008 
Koepfli, K.-P. \& Wayne, R. K. 1998. Phylogenetic relationships of otters (Carnivora: Mustelidae) based on mitochondrial cytochrome b sequences. Journal Zoology 246:401-416.

2003. Type I STS Markers are more informative than Cytochrome $\mathrm{b}$ in Phylogenetic reconstructin of the Mustelidae (Mammalia: carnivora). Systematic Biology 52:571-593.

Kohn, M. H.; York, E. C.; Kamradt, D. A.; Haught, G.; Sauvajot, R. M. \& Wayne, R. K. 1999. Estimating population size by genotyping faeces. Proceedings of the Royal Society of London B 266:657-663.

Larivière, S. 1999. Lontra longicaudis. Mammalian Species 609: $1-5$

Larson, S.; Jameson, R.; Bodkin, J.; Staedler, M. \& Bentzen, P. 2002a. Microsatellite DNA and mitochondrial DNA variation in remmant and translocated sea otter (Enhydra lutris) populations. Journal of Mammalogy 83:893-906.

Larson, S.; Jameson, R.; Etnier, M.; Flemming, M. \& Bentzen, P. 2002b. Loss of genetic diversity in sea otters (Enhydra lutris) associated with the fur trade of the $18^{\text {th }}$ and $19^{\text {th }}$ centuries. Molecular Ecology 11:1899-1903.

Levene, H. 1949. On a matching problem arising in genetics. Annals of Mathematical Statistics 20:91-94.

MacDonald, S. \& Mason, C. 1990. Threats. In: Foster-Turley, P.; Macdonald, S. \& Mason, C. eds. Otters. An Action Plan for their Conservation. California, IUCN Publication Services Unit. p.11-14.

Mason, C. 1990. An introduction to the Otters. In: FosterTurley, P.; Macdonald, S. \& Mason, C. eds. Otters. An Action Plan for their Conservation. California, IUCN Publication Services Unit. p.4-7.

Melquist, W. E. 1984. Status of Otters (Lutrinae) and spotted cats (Felidae) in Latin America. Report to IUCN. College of Forestry, Wildlife, and Range Sciences. Idaho, University of Idaho. p.267.

MMA (Ministério do Meio Ambiente). 1999. First National Report for the Convension on Biological Diversity Brazil. Brasília, MMA. p.272.

2003. Lista das Espécies da Fauna Brasileira Ameaçadas de Extinção. Normative Instruction $n^{\circ} 3,27$ th of May, 2003. Brasília, MMA. p.19.

Morin, P. A.; Chambers, K. E.; Boesch, C. \& Vigilant, L. 2001. Quantitative polymerase chain reaction analysis of DNA from noninvasive samples for accurate microsatellite genotyping of wild chimpanzees (Pan troglodytes verus). Molecular Ecology 10:1830-1844.

Morin, P. A. \& WoodrufF, D.S. 1996. Noninvasive genotyping for Vertebrate conservation. In: Sмiтh, T. B. \& Wayne, R. K. eds. Molecular Genetics Approaches in Conservation. New York, Oxford University. p.298-313.

Navidi, W.; Arnheim, N. \& Waterman, M. S. 1992. A multipletubes approach for accurate genotyping of very small DNA samples by using PCR: statistical considerations. American Journal of Human Genetics 50:347-359.
NeI, M. 1978. Estimation of average heterozygosity and genetic distance from small number of individuals. Genetics 89:583-590.

Nsubuga, A. M.; Robbins, M. M.; Roeder, A. D.; Morin, P. A.; Boesch, C. \& Vigilant, L. 2004. Factors affecting the amount of genomic DNA extracted from ape faeces and the identification of an improved storage method. Molecular Ecology 13:2089-2094.

Piggott, M. P.; Bellemain, E.; Taberlet, P. \& Taylor, A. C. 2004. A multiplex preamplification method that significantly improves microsatellite amplification and errors rate for faecal DNA in limited conditions. Conservation Genetics 5:417-420.

Queller, D. C. \& Goodnight, K. F. 1989. Estimating relatedness using genetic markers. Evolution 43:258-275.

Raymond, M. \& Rousset, F. 1995. GENEPOP (v. 1.2) population genetics software for exact tests and ecumenicism. Journal of Heredity 86:218-219.

Rice, W. R. 1988. Analyzing tables of statistical tests. Evolution 43:223-225.

Rosas, F. C. W.; Colares, E. P.; Colares, I. G. \& Silva, V. M. F. 1991. Mamíferos aquáticos da Amazônia brasileira. In: VAL, A. L.; Figliuolo, R. \& Feldsberg, E. eds. Bases científicas para o estabelecimento de estratégias de preservação e desenvolvimento da Amazônia: fatos e perspectivas. Manaus, FUA. p.405-411.

SEMA (Secretaria Especial do Meio Ambiente). 1977. Programa de Estações Ecológicas. Meio Ambiente 2. Brasília, Ministério do Interior. p. 42.

Swofford, D. M. \& Selander, R. B. 1981. BIOSYS-1: a Fortran program for the comprehensive analysis of electrophoretic data in population genetics and systematics. Journal of Heredity 72:281-283.

Taberlet, P.; Camarra, J. J.; Griffin, S.; Uhrès, E.; Hanotte, O.; Waits, L. P.; Dubois-Paganon, C.; Burke, T. \& Bouvet, J. 1997. Noninvasive genetic tracking of the endangered Pyrenean brown Bear population. Molecular Ecology 6:869-876.

Trujlllo, R. G.; Loughlin, T. R.; Gemmell, N. J.; Patton, J. C. \& BiскнАм. 2004. Variation in microsatellites and mtDNA across the range of the steller sea lion, Eumetopias jubatus. Journal of mammalogy 85:338-346.

UNEP-WCMC. 2003. Checklist of CITES species. Available at: <http://sea.unep-wcmc.org/isdb/CITES/Taxonomy>. Accessed on: 01.08.2005.

Waits, L. P.; Luikart, G. \& Taberlet, P. 2001. Estimating the probability of identity among genotypes in natura populations: cautions and guidelines. Molecular Ecology 10:249-256.

Wasser, S. K.; Houston, C. S.; Koehler, G. M.; Cadd, G. G. \& Fain, S. R. 1997. Techniques for application of faecal DNA methods to field studies of Ursids. Molecular Ecology 6:1091-1097.

WurfF, A. W. G. van der; Gols, R.; Ernsting, G.; van Straalen, N. M. 2005. Population genetic structure of Orchesella cincta (Collembola; Hexapoda) in NW Europe, as revealed by microsatellite markers. Pedobiologia 49:167-174.

Recebido em março de 2006. Aceito em junho de 2008. ISSN 0073-4721

Artigo disponível em: www.scielo.br/isz 